\title{
X-ray crystallography of krinovite
}

By Stefano MerLino

Institute of Mineralogy and Petrography, University of Pisa*

(Received 20 November 1970, and in revised form 18 October 1971)

\begin{abstract}
Auszug
Das meteoritische Mineral Krinowit, $\mathrm{NaMg}_{2} \mathrm{CrSi}_{3} \mathrm{O}_{10}$ ist triklin. Seine Gitterkonstanten sind : $a=10,22, b=10,67, c=8,80 \AA, \alpha=105^{\circ} 8^{\prime}, \beta=96^{\circ} 36^{\prime}$, $\gamma=125^{\circ} 1^{\prime}$. Die von OLSwe und Fuchs angegebene Elementarzelle ist eine der möglichen pseudomonoklinen Zellen. Der Krinowit ist polysynthetisch verzwillingt mit $b$ als Zwillingsachse. Auf die nahe Verwandtschaft von Krinowit, Aenigmatit und Rhönit wird hingewiesen. Für den Krinowit wird ein Strukturvorschlag gemacht; als kristallchemische Formel ergab sich
\end{abstract}

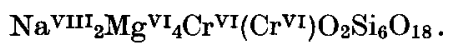

\section{Abstract}

The unit cell of the meteoritic mineral krinovite, $\mathrm{NaMg}_{2} \mathrm{CrSi}_{3} \mathrm{O}_{10}$, is triclinic with $a=10.22, b=10.67, c=8.80 \AA, \alpha=105^{\circ} 8^{\prime}, \beta=96^{\circ} 36^{\prime}, \gamma=125^{\circ} 1^{\prime}$. The monoclinic unit cell given by OLSEN and Fuchs is one of the possible pseudomonoclinic cells. Krinovite is polysynthetically twinned with the $b$ axis of the pseudomonoclinic cell as twin axis. The close relationships among krinovite, aenigmatite and rhönite are shown. The crystal structure of krinovite is suggested and the crystallochemical formula $\mathrm{Na}^{\mathrm{VIII}}{ }_{2} \mathrm{MgVI}_{4} \mathrm{Cr} \mathrm{rI}_{(\mathrm{Cr}} \mathrm{CI}_{2} \mathrm{O}_{2} \mathrm{Si}_{6} \mathrm{O}_{18}$ is derived.

\section{Introduction}

Krinovite was found by OLSEN and Fuchs (1968) as minute crystals disseminated within graphite nodules in octahedrite iron meteorites from Canyon Diablo, United States, Wichita County, United States and Youndegin, Australia. The chemical composition, determined by electron microprobe, corresponds to the ideal formula $\mathrm{NaMg}_{2} \mathrm{CrSi}_{3} \mathrm{O}_{10}$.

Using a Weissenberg camera OLSEN and FUCHS found a monoclinic symmetry with unit-cell dimensions $a=19.48, b=29.18, c=10.25 \AA$, $\beta=103^{\circ}$. They observed that a space group could not be assigned because of prominent twinning.

* Stefano Merlino, Istituto di Mineralogia e Petrografia, Via S. Maria 53. I-56100 Pisa, Italy. 
It can be seen that a close relationship exists between the chemical composition of krinovite and that of aenigmatite whose unit cell contents are represented by the ideal formula $\mathrm{Na}_{4} \mathrm{Fe}_{10} \mathrm{Ti}_{2} \mathrm{Si}_{12} \mathrm{O}_{40}$. Moreover it is noteworthy that the triclinic cell of aenigmatite can be described in terms of a pseudomonoclinic cell with parameters $a=19.776$, $b=29.628, c=10.406 \AA, \beta=102^{\circ} 21^{\prime}$, which are closely similar to the corresponding parameters given by OLSEN and FuCHS for the unit cell of krinovite.

On this basis the author made the hypothesis that krinovite also had a triclinic unit cell, strictly related to that of aenigmatite, and the parameters given by OLSEN and FuCHS determined a pseudomonoclinic cell. The present work was undertaken with the aim to verify this hypothesis.

\section{X-ray crystallography}

A specimen of krinovite from the iron meteorite of Wichita County was donated by L. Fuchs. It was composed of very minute emeraldgreen crystal fragments without any apparent morphology, but generally elongated along the $c$ axis of the Olsen and Fuchs cell (which henceforth will be indicated as OF cell).

A rotating-crystal photograph and Weissenberg photographs of several successive layers for rotation about the OF $c$ axis were taken. The rotation photograph appeared very similar, as regards both positions and intensities of the spots, to a rotating crystal photograph of aenigmatite for rotation about the $a$ axis of the triclinic cell.

From the Weissenberg photographs the diffraction pattern reported in Fig. 1 was obtained; this is easily explained as due to a reciprocal lattice like that represented in Fig.2, twinned with normal to the drawing plane as twinning axis. In the diffraction pattern, the intensities as well as the positions of reflections are symmetrical with respect to the twinning axis, which indicates equality of volumes of the two individuals. The occurrence of this situation in all the crystals examined suggests that polysynthetic twinning occurs, with individuals rather small.

The occurrence of polysynthetic twinning makes more strict the similarity between krinovite and aenigmatite: in fact aenigmatite from volcanic parageneses is polysynthetically twinned, with the normal to the (010) plane of the pseudomonoclinic cell as twin axis. It can be observed at this point that polysynthetic twinning occurs in another mineral, closely related to aenigmatite, namely rhönite $\mathrm{Ca}_{4}\left(\mathrm{Mg}, \mathrm{Fe}^{+2}\right)_{8}$ - 


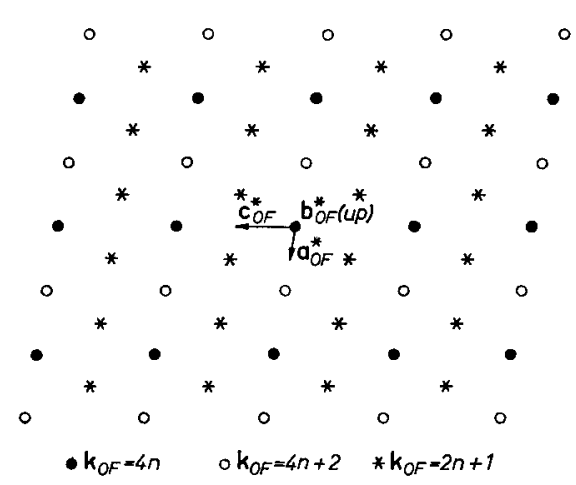

Fig. 1. Drawing of the diffraction pattern of krinovite. Positions but not intensities of the reflections are shown. Reciprocal-lattice parameters corresponding to the Olsen and Fuchs pseudomonoclinic cell are indicated

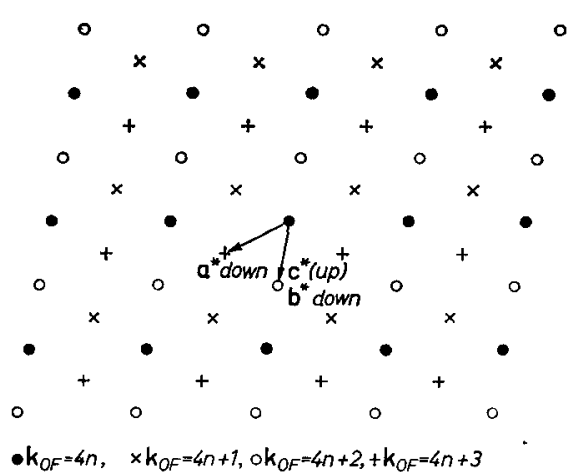

Fig. 2. Drawing of the reciprocal lattice of krinovite, viewed along the $b$ axis of the pseudomonoclinic cell. The drawing plane is (01) $)$. Parameters of the triclinic reciprocal cell are indicated. The $a^{*}$ vector ends at the level $k_{\mathrm{OF}}=-1$; the $b^{*}$ and $c^{*}$ vectors end respectively at the levels $k_{\mathrm{OF}}=-2$ and $k_{\mathrm{OF}}=2$

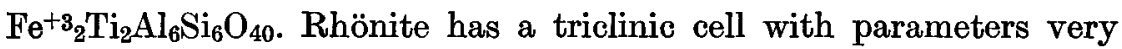
similar to those of aenigmatite and its twin axis also is normal to the (010) plane of the pseudomonoclinic cell.

A triclinic unit cell corresponds to the reciprocal lattice of Fig. 2. The cell of OLSEN and FUCHS is one of the several pseudomonoclinic cells that can be chosen; the most simple of these has the following parameters: $a_{\mathrm{m}}=10.04 \pm 0.01, \quad b_{\mathrm{m}}=29.26 \pm 0.03, \quad c_{\mathrm{m}}=10.22$ $\pm 0.01 \AA, \beta_{\mathrm{m}}=107^{\circ} 54^{\prime} \pm 10^{\prime}$.

It can be noted that, as in the diffraction pattern of rhönite (WALENTA, 1969), no splitting of reflections was observed. This means 
that $\alpha_{\mathrm{m}}$ and $\gamma_{\mathrm{m}}$ angles of the pseudomonoclinic cell don't differ sensibly from $90^{\circ}$. The other parameters were obtained by high-angle reflection measurements on zero-layer Weissenberg photographs with rotation about $b_{\mathrm{m}}$ and $c_{\mathrm{m}}$. A back-reflection camera, calibrated with a quartz crystal, was used. Wavelengths of $\mathrm{Cu} K \alpha$ radiation were assumed as $\lambda\left(\mathrm{Cu} K \alpha_{1}\right)=1.5405$ and $\lambda\left(\mathrm{Cu} K \alpha_{2}\right)=1.5443 \AA$.

The problem of fixing the triclinic cell was solved in the case of aenigmatite by KELSEY and MoKIE (1964) who determined the Delauney cell. The parameters of the corresponding cell for krinovite can be obtained from the measured parameters of the pseudomono-

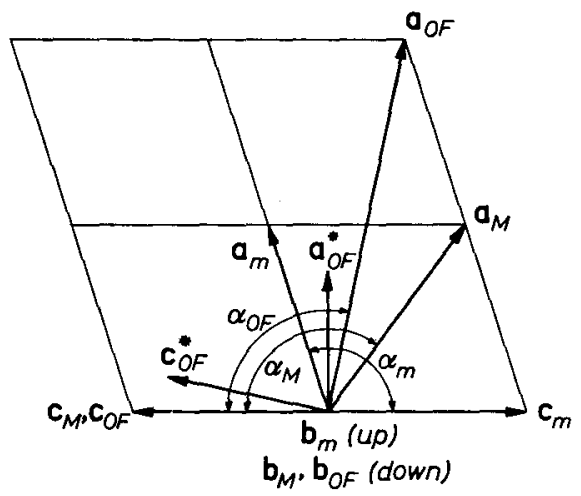

Fig. 3. Schematic drawing showing the different ways of choosing the pseudomonoclinic cell of krinovite. The drawing plane is $(01 \tilde{\mathbf{I}})_{t}$

clinic cell by the transformation matrix $\left[00 \overline{1} / \frac{1}{2} \frac{1}{4} \frac{3}{4} / \frac{1}{2} \frac{1}{4} \cdot \frac{1}{4}\right]: a=10.22$, $b=10.67, c=8.80 \AA, \alpha=105^{\circ} 8^{\prime}, \beta=96^{\circ} 36^{\prime}, \gamma=125^{\circ} 1^{\prime}$. In accordance with KELSEY and McKIE, the axes are labelled such that $c<a<b$. KELSEY and McKie give also the dimensions of the reduced cell (BUERGER, 1957) of aenigmatite. The corresponding cell for krinovite has the following dimensions: $a_{\text {red }}=9.67, b_{\text {red }}=10.22, c_{\text {red }}$ $=8.80 \AA, \alpha_{\text {red }}=83^{\circ} 24^{\prime}, \beta_{\text {red }}=65^{\circ} 46^{\prime}, \gamma_{\text {red }}=64^{\circ} 53^{\prime}$. The matrix for the transformation Delauney cell $\rightarrow$ reduced cell is $[110 / 100 / 00 \overline{1}]$ and that for the inverse transformation is $[010 / 1 \overline{1} 0 / 00 \overline{1}]$.

Too many pseudomonoclinic cells of aenigmatite have been introduced in crystallographic literature in these last years and the author has also given his contribution to such proliferation. Partly to make amends for this, Figs. 3 and 4 and Table 1 are presented to show the relations of the various pseudomonoclinic cells each other and the 
variations of the parameters of each cell in the different minerals, namely aenigmatite, rhönite and krinovite.

The $m$ pseudomonoclinic cell was introduced by CANNILLo and MAZZI (1970) to describe the crystal structure of aenigmatite, and by WALENTA (1969) in his paper on the crystallography of rhönite. The M cell was introduced by the author (MERLINo, 1970) in his paper on the crystal structure of aenigmatite, to show the close relationship between this pseudomonoclinic cell of aenigmatite and the true monoclinic cell of sapphirine. The OF cell was given by OLSEN and FuCHS (1968) for krinovite. KELSEY and McKIE (1964) proposed for aenig-

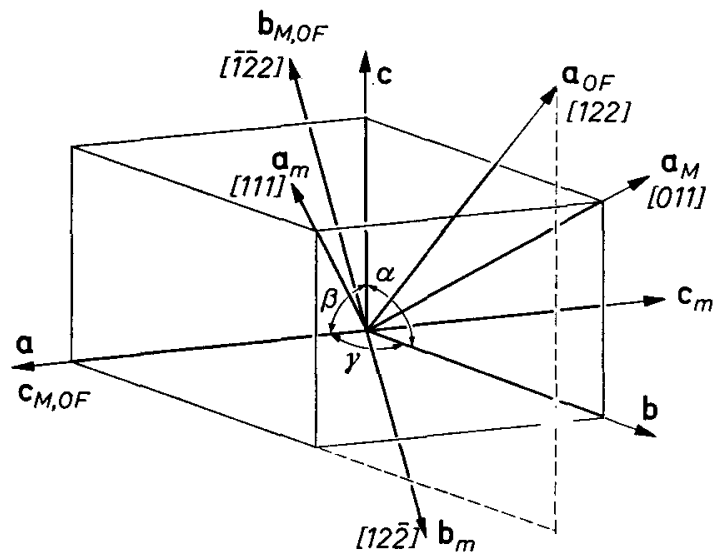

Fig.4. The drawing shows the directions of the axes of the various pseudomonoclinic cells referred to the system of the triclinic cell

matite a pseudomonoclinic cell with $a=9.888, b=\mathbf{1 4 . 8 1 4}, c=\mathbf{5 . 2 0 3} \AA$ and $\beta=102^{\circ} 21^{\prime}$, which obviously correspond to an OF cell with halved parameters. KELSEY and McKre clearly stated that the $b$ and $c$ parameters of their pseudomonoclinic cell had to be doubled to obtain true translations; however they forgot to make a similar statement for the $a$ axis. Consequently WALEnTA (1969) assumed erroneously a correspondence between the $m$ cell of rhönite and the Kelsey and McKie pseudomonoclinic cell of aenigmatite; moreover he used the transformation matrix given by KELSEY and MCKIE, to obtain the parameters of the triclinic cell, which were thus significantly in error. The correctly calculated parameters of the triclinic cell of rhönite are given in Table 1. The last column of this table gives the transformation matrices for obtaining the various pseudomonoclinic cells from the triclinic cell. 


\section{Structural considerations}

The $x$-ray crystallography and the chemical composition of krinovite strongly suggest a very close structural relationship of this mineral with aenigmatite, the crystal structure of which has been simultaneously and independently determined by the author (MERLINo, 1970) and by CANNILlo and MazzI (1970). The structural relationship has been confirmed by a careful comparison of corresponding $x$-ray diffraction photographs of the two minerals. The author is collecting $x$-ray diffraction data to make a complete structural study of krinovite; however some considerations can already be made with confidence.

The crystal structure of aenigmatite can be described by means of the three structural units found by Moore $(1968,1969)$ in sapphirine:

(a) octahedral walls, which run parallel to the $a$ axis of the triclinic cell (or the $c_{m}$ axis) and oriented parallel to the $(011)=(100)_{m}$ plane (the expression "octahedral walls" is maintained to simplify description though, owing to deviations from the ideality of the polyhedral arrangements, the sodium ions reach eightfold coordination ${ }^{1}$ ). In the "octahedral walls" titanium ions are ordered on a particular site.

(b) Tetrahedral chains $\mathrm{Si}_{6} \mathrm{O}_{18}$ running parallel to the $a=c_{m}$ axis.

(c) Octahedra, occupied by iron ions, placed between walls and sharing edges with the walls above and below.

The crystal structure of krinovite is substantially similar, with the following modifications: chromium ions substitute for titanium in octahedral walls and for iron ions in octahedra between walls; magnesium ions substitute for the remaining iron ions. Thus from the crystallochemical formula $\mathrm{NaVIII}_{2} \mathrm{Fe}^{\mathrm{VI}} \mathrm{Ti}_{4} \mathrm{VI}\left(\mathrm{Fe}^{\mathrm{VI}}\right) \mathrm{O}_{2} \mathrm{Si}_{6} \mathrm{O}_{18}$ of aenigmatite, we obtain for krinovite the formula:

$$
\mathrm{Na}^{\mathrm{VIII}}{ }_{2} \mathrm{Mg} \mathrm{CI}_{4} \mathrm{CrVI}(\mathrm{CrVI}) \mathrm{O}_{2} \mathrm{Si}_{6} \mathrm{O}_{18} \text {, }
$$

where, following Moore $(1968,1969)$, the parentheses include the octahedral cations placed between walls. The location of chromium atoms was conjectured on the basis of PAULING's electrostatic valence rule and, though very probable, must be confirmed by the complete structural determination.

This work was supported by Consiglio Nazionale delle Ricerche, Roma.

\footnotetext{
1 CANNILLO and MAZZI, personal communication.
} 


\section{References}

M. J. Buerger (1957), Roduced cells. Z. Kristallogr. 109, 42-60.

E. Cannillo e F. Mazzi (1970), La struttura cristallina dell'enigmatite $\mathrm{Na}_{2} \mathrm{Fe}_{5}$ $\mathrm{TiO}_{2} \mathrm{Si}_{6} \mathrm{O}_{18}$. IV Convegno Associazione Italiana di Cristallografia. Relazion i presentate dai soci, 121-123.

C. H. KeLsey and D. McKIE (1964), The unit cell of aenigmatite. Miner. Mag. 33, 986-1001.

S. Merlino (1970), Crystal structure of aenigmatite. Chem. Communic. $1288-1289$.

P. B. Moone (1968), Crystal structure of sapphirine. Nature 218, 81-82.

P. B. Moore (1969), The crystal structure of sapphirine. Amer. Mineralogist 54, $31-49$.

E. OLSEN and L. Fuchs (1968), Krinovite, $\mathrm{NaMg}_{2} \mathrm{CrSi}_{3} \mathrm{O}_{10}$ : a new meteorite mineral. Science 161, 786--787.

K. WALENTA (1969), Zur Kristallographie des Rhönits. Z. Kristallogr. 130, $214-230$. 